\title{
Characteristics and genetic determinant of a hydrophobic peptide bacteriocin, carnobacteriocin A, produced by Carnobacterium piscicola LV17A
}

\author{
Randy W. Worobo, ${ }^{3}$ Thomas Henkel, ${ }^{1}$ Miloslav Sailer, ${ }^{1}$ Kenneth L. Roy, ${ }^{2}$ \\ John C. Vederas ${ }^{1}$ and Michael E. Stiles ${ }^{3}$
}

Author for correspondence: Michael E. Stiles. Tel: +1 403492 2386. Fax +1 4034928914.

Departments of 'Chemistry, 2Microbiology and ${ }^{3}$ Food Science and Nutrition, University of Alberta, Edmonton, Alberta, Canada T6G 2P5

\begin{abstract}
Carnobacteriocin A is a hydrophobic nonlantibiotic bacteriocin that is detected early in the growth cycle of Carnobacterium piscicola LV17A and encoded by a 49 MDa plasmid. The bacteriocin was purified using hydrophobic interaction and gel filtration chromatography, and reversed-phase HPLC. Three different active peaks (A1, A2 and A3) were detected, but the purified samples had identical $\mathbf{N}$-terminal amino acid sequences for the first 15 amino acids as determined by Edman degradation analysis. Only a $2.4 \mathrm{~kb}$ fragment of the EcoRI digest of the plasmid pCP49 hybridized with a 23-mer oligonucleotide probe derived from amino acids 5 to 13 of the amino acid sequence. The structural gene for carnobacteriocin $A$ is located 600 base pairs into the $2.4 \mathrm{~kb}$ EcoRI fragment, but no other genetic information was detected on this unit. The structural gene includes an 18 amino acid $\mathbf{N}$-terminal extension of the bacteriocin, ending with Gly-Gly residues in the $-2,-1$ positions with respect to the cleavage site. The bacteriocin consists of 53 amino acids that differ markedly from the majority of hydrophobic peptide bacteriocins characterized to date. Based on the amino acid sequence derived from the nucleotide sequence a molecular mass of 5052.85 Da was calculated. Mass spectrometric analysis showed that the molecular mass of the major component (A3) was $2 \mathrm{Da}$ lower, thereby indicating the presence of a disulphide bridge between Cys 22 and Cys 51. Carnobacteriocin A2 has a similar structure except that Met 52 is oxidized to a sulphoxide, whereas $A 1$ appears to be a mixture of peptides derived proteolytically from $A 3$ or A2.
\end{abstract}

Keywords: bacteriocin, lactic acid bacteria, Carnobacterium piscicola, carnobacteriocin A, meat

\section{INTRODUCTION}

The lactic acid bacterium Carnobacterium piscicola LV17, isolated from the adventitious microflora of vacuumpackaged meat as an 'atypical Lactobacillus-type' organism (Shaw \& Harding, 1984), produces heat-stable bacteriocins that are detected early in the growth cycle (Ahn \& Stiles, 1990a, b). The parent strain contains three plasmids. Separation of the plasmids revealed that 'early' bacteriocin production is mediated by the $49 \mathrm{MDa}$

Abbreviations: $\mathrm{AU}$, (arbitrary) activity units; $\mathrm{MeCN}$, acetonitrile; TFA, trifluoroacetic acid.

The GenBank accession number for the sequence reported in this paper is L23112. plasmid (Ahn \& Stiles, 1992). Bacteriocins are proteinaceous, antimicrobial compounds that typically inhibit closely related bacteria (Klaenhammer, 1988). Nisin A produced by Lactococcus lactis subsp. lactis has been extensively studied and is used commercially as a food preservative (Delves-Broughton, 1990), but its applications are limited by its insolubility and instability at $\mathrm{pH}>$ 5. Interest in the use of bacteriocins for food preservation has increased with the discovery of many new active compounds produced by lactic acid bacteria (Klaenhammer, 1988). Some of these have been extensively characterized to reveal new 'classes' of bacteriocins, including heat-stable, low molecular mass, hydrophobic nonlantibiotic compounds: lactacin F from Lactobacillus acidophilus (Muriana \& Klaenhammer, 1991); lactococcin 
A from Lactococcus lactis subsp. cremoris (Holo et al., 1991); leucocin A-UAL187 from Leuconostoc gelidum (Hastings et al., 1991); mesentericin Y105 from Leuconostoc mesenteroides subsp. mesenteroides (Héchard et al., 1992); pediocin PA-1 from Pediococcus acidilactici (Marugg et al., 1992; Lozano et al., 1992); and sakacin A from Lactobacillus sake (Holck $e t$ al., 1992). All of these compounds, except for mesentericin Y105, have been shown to be ribosomally synthesized with an $\mathrm{N}$-terminal extension to the structural peptide that is cleaved at a peptide bond adjacent to a common Gly-Gly $(-2,-1)$ site.

Elucidation of the amino acid sequences of the widely reported pediocin PA-1/AcH (Motlagh et al., 1992; Henderson et al., 1992; Lozano et al., 1992) revealed that these bacteriocins are the same compound. Exceptional similarity exists between leucocin $A$ and mesentericin Y105, despite the different sources of the producer strains. They consist of 37 amino acids with variation only in amino acid residues 22 and 26 , yet the activity spectra are strikingly different (Hastings et al., 1991; Héchard et al., 1992; Y. Cenatiempo, personal communication). Similarly, there is considerable homology between the first 20 amino acids of leucocin A, pediocin PA-1, sakacins A and P, and curvacin A (Hastings et al., 1991; Marugg et al., 1992; Holck et al., 1992; Tichaczek et al., 1992). Many other bacteriocins may possess analogous sequences but lack of structural characterization limits the information that can be interpreted from reports of their occurrence. Complete elucidation of the amino acid sequence and the genetic determinants of bacteriocin activity can provide insight into the structure and function relationships and modes of action of these compounds. It is also a prerequisite for determination of three-dimensional structure by NMR spectrometry (Henkel et al., 1992; Sailer $e t$ al., 1993). In this study we describe the characteristics of carnobacteriocin A produced by Carnobacterium piscicola LV17A, including the complete amino acid sequence and the nucleotide sequence for the structural gene involved in synthesis of this bacteriocin.

\section{METHODS}

Bacteriology. The bacteriocin-producing organism C. piscicola LV17 was identified as a nonaciduric 'Lactobacillus' isolated from vacuum-packaged meat by B. G. Shaw (AFRC Institute of Food Research, Langford, Bristol, UK). The parent strain contains three plasmids (Ahn \& Stiles, 1990b). Strains LV17A and LV17A.17 are bacteriocinogenic $\left(\mathrm{Bac}^{+}\right)$and contain the $49 \mathrm{MDa}$ plasmid or a $17 \mathrm{MDa}$ religated $B g / \mathrm{II}$ fragment of pCP49, respectively (Ahn \& Stiles, 1992). Production of bacteriocin was monitored against $C$. divergens LV13 (from B. G. Shaw) by a spot-on-lawn technique (Ahn \& Stiles, 1990b). Cultures were stored in Cooked Meat Medium (Difco) at $4{ }^{\circ} \mathrm{C}$ and at $-70{ }^{\circ} \mathrm{C}$ in APT broth (Difco) at pH 6.5 containing $20 \%$ (v/v) glycerol. Stock cultures were subcultured in APT at $25^{\circ} \mathrm{C}$ on two successive days before use in an experiment. Growth of C. piscicola LV17A for bacteriocin purification was done in semidefined medium (CAA) as described by Hastings et al. (1991). Escherichia coli strains were grown in Luria-Bertani (LB; Sambrook et al., 1989) broth or agar at $37^{\circ} \mathrm{C}$, and stored at $-70{ }^{\circ} \mathrm{C}$ in $\mathrm{LB}$ broth with $20 \%$ glycerol. The bacterial strains and plasmids used in this study are listed in Table 1.
Purification of carnobacteriocin A. The procedure was adapted from Sailer et al. (1993). The producer strain was grown at $25^{\circ} \mathrm{C}$ in 2 litres of $\mathrm{CAA}$ adjusted to and maintained at $\mathrm{pH} 6.2$ with sterile $1 \mathrm{M} \mathrm{NaOH}$ using a $\mathrm{pH}$ stat (Chem-Cadet, Cole Palmer) while being stirred gently under a steady flow of nitrogen $\left(40 \mathrm{ml} \mathrm{min}^{-1}\right)$. After $16 \mathrm{~h}(\mathrm{NaOH}$ consumption $150 \mathrm{ml})$ the supernatant fluids were collected by centrifugation at $8000 \mathrm{~g}$ for $20 \mathrm{~min}$ at $4{ }^{\circ} \mathrm{C}$. The culture supernatant $(2150 \mathrm{ml})$ was applied directly to an Amberlite XAD-8 column $(4.5 \times 45 \mathrm{~cm}$; BDH Chemicals) washed with 2 litres of $0.1 \%$ trifluoroacetic acid (TFA), and eluted with successive 1 litre volumes of $20,30,45$ and $80 \%(\mathrm{v} / \mathrm{v})$ ethanol in $0.1 \%$ TFA. Active fractions were combined and concentrated to $30 \mathrm{ml}$ using a rotary evaporator at $30^{\circ} \mathrm{C}$, mixed with the same volume of acetonitrile $(\mathrm{MeCN})$ and loaded onto a Sephadex LH- 60 column $(5 \times 25 \mathrm{~cm})$ that had been equilibrated with $50 \%(\mathrm{v} / \mathrm{v}) \mathrm{MeCN}$ in $0.1 \%$ aqueous TFA. The active fractions were pooled and concentrated to $5 \mathrm{ml}$ by rotary evaporation. The concentrate was applied in $0.5 \mathrm{ml}$ portions to a $\mathrm{C}_{8}$ HPLC column (VYDEC, $10 \times 250 \mathrm{~mm}, 10 \mu \mathrm{m}$, $300 \AA$, flow rate $3 \mathrm{ml} \mathrm{min}^{-1}$, mobile phase: $\mathrm{A}, 0.1 \%$ TFA in water; $\mathrm{B}, 70 \%$ acetonitrile in $0.1 \%$ TFA) and eluted using a gradient method: first $43 \%$ to $54 \%$ B solvent in 4 min and then $54 \%$ to $61 \% \mathrm{~B}$ in $7 \mathrm{~min}$. Fractions were monitored for absorbance at $218 \mathrm{~nm}$ and activity against the indicator strain. Purifications of separated active peptides were completed by isocratic elution on the same column (flow rate $3.5 \mathrm{ml} \mathrm{min}^{-1}$, in $46 \%, 55 \%$ and $57 \%$ of $\mathrm{B}$ solvent for $\mathrm{A} 1, \mathrm{~A} 2$ and $\mathrm{A} 3$, respectively).

Stability of carnobacteriocins A. The effects of $\mathrm{pH}$, heat treatment, and selected organic solvents on the activity of purified carnobacteriocins A1 [1600 arbitrary units (AU) $\mathrm{ml}^{-1}$ ], A2 $\left(200 \mathrm{AU} \mathrm{ml}^{-1}\right)$, and $\mathrm{A} 3\left(400 \mathrm{AU} \mathrm{m}^{-1}\right)$ were determined. Samples were suspended in the following buffers: $\mathrm{pH} 1.0$ and 3.0 glycine $/ \mathrm{HCl}(50 \mathrm{mM}$ and $30 \mathrm{mM}$, respectively), $\mathrm{pH} 5.0$ in citric acid/ $\mathrm{HCl}(50 \mathrm{mM}), \mathrm{pH} 7 \cdot 0$ and $9 \cdot 0$ in Tris buffer $(50 \mathrm{mM})$ adjusted with $\mathrm{HCl}$. Samples at each $\mathrm{pH}$ were heated in a boiling water bath for 30 min. Residual activity was determined after 2 and $24 \mathrm{~h}$ at each pH level and immediately after heat treatment. To test effects of organic solvents, the carnobacteriocins were suspended in $50 \%(\mathrm{v} / \mathrm{v})$ solutions of aqueous $0.1 \%$ TFA with acetone, acetonitrile, ethanol, ethyl acetate, methanol and tetrahydrofuran. Lyophilized samples were also dissolved in $0.1 \%$ TFA, stored at $5{ }^{\circ} \mathrm{C}$ for $14 \mathrm{~d}$, and checked by HPLC. Degradation was estimated from the appearance of decomposed products and residual activity.

Determination of $\mathbf{N}$-terminal amino acid sequence of carnobacteriocin A. Purified carnobacteriocins from C. piscicola LV17A were subjected to Edman degradation analysis on an automated gas-phase sequencer (Applied Biosystems model $470 \mathrm{~A}$ ) with on-line phenylthiohydantoin derivative identification by reversed-phase HPLC (Applied Biosystems model 120A).

Mass spectrometry of carnobacteriocins. All mass spectra were kindly acquired by Dr Robert B. Cody at Jeol USA (Peabody, MA) on a Jeol SX102A instrument using an electrospray interface for fast atom bombardment mass spectrometry (FAB MS) in the positive ion mode. Samples of A1, $\mathrm{A} 2$, and A3 obtained by HPLC purification were dissolved in $1: 1(\mathrm{v} / \mathrm{v})$ aqueous methanol containing $2 \%(\mathrm{v} / \mathrm{v})$ glacial acetic acid and were analysed by direct infusion through a sample loop. Jeol software was employed to determine molecular masses from the envelopes of multiply charged peaks in the $\mathrm{m} / \mathrm{z}$ spectra.

SDSPAGE. Purified carnobacteriocin preparations were examined using $20 \%(\mathrm{w} / \mathrm{v})$ polyacrylamide gels and $3 \mathrm{M}$ Tris $/ \mathrm{HCl}$, 
Table 1. Bacteria and plasmids used to study bacteriocin production by $C$. piscicola LV17A

\begin{tabular}{|c|c|c|}
\hline $\begin{array}{l}\text { Bacterial strain or } \\
\text { plasmid/phage type }\end{array}$ & Description* & Source or reference \\
\hline \multicolumn{3}{|l|}{ Carnobacterium piscicola } \\
\hline LV17A & $\mathrm{Bac}^{+} \mathrm{Imm}^{+}$containing $\mathrm{pCP} 49$ & Ahn \& Stiles (1990b) \\
\hline LV17A.17 & $\begin{array}{l}\mathrm{Bac}^{+} \mathrm{Imm}^{+} \text {containing } 17 \mathrm{MDa} B g l \mathrm{II} \text { religated fragment } \\
\text { of pCP49 }\end{array}$ & Ahn \& Stiles (1992) \\
\hline LV17B & $\mathrm{Bac}^{+} \mathrm{Imm}^{+}$containing $\mathrm{pCP} 40$ & Ahn \& Stiles (1990b) \\
\hline \multicolumn{3}{|l|}{ Carnobacterium divergens } \\
\hline $\begin{array}{l}\text { Escherichia coli } \\
\text { MV } 1193\end{array}$ & $\begin{array}{l}\Delta(\text { lac-pro } A B) r p s L \text { thr end } A \text { spcB15 hsdR } 4 \Delta(\operatorname{srl}-\operatorname{rec} A) \\
\text { 306: : Tn10 }\left(\operatorname{Tet}^{\mathrm{r}}\right) \mathrm{F}^{\prime}\left[\operatorname{tra} D_{36} \text { pro } A B^{+} \text {lacI } I^{\mathrm{a}} \text { lacZ } \Delta \mathrm{M} 15\right]\end{array}$ & Sambrook et al. (1989) \\
\hline \multicolumn{3}{|l|}{ Plasmids } \\
\hline pUC118 & $\operatorname{lac} Z^{\prime} \mathrm{Ap}^{\mathrm{r}}, 3 \cdot 2 \mathrm{~kb}$ & Vieira \& Messing (1987) \\
\hline pK194 & lac $Z^{\prime} \mathrm{Km}^{\mathrm{r}}, 2 \cdot 4 \mathrm{~kb}$ & Jobling \& Holmes (1990) \\
\hline pRW5.9U & $\mathrm{Ap}^{r} \operatorname{cbn} A, 5.9 \mathrm{~kb}$ & This study \\
\hline pRW $4.4 \mathrm{~K}$ & $\mathrm{Km}^{\mathrm{r}} \operatorname{cbn} A, 4 \cdot 4 \mathrm{~kb}$ & This study \\
\hline \multicolumn{3}{|l|}{ Phage } \\
\hline M13K07 & Helper phage for pUC118 & Sambrook et al. (1989) \\
\hline
\end{tabular}

* $\mathrm{Bac}^{+}$, production of carnobacteriocin $\mathrm{A} ; \mathrm{Imm}^{+}$, immunity to carnobacteriocin $\mathrm{A}$.

$\mathrm{pH} 8 \cdot 8$, as described by Laemmli (1970). Electrophoresis was done at constant current of $20 \mathrm{~mA}$. Gels were fixed in $5 \%(\mathrm{v} / \mathrm{v})$ formaldehyde for $30 \mathrm{~min}$ and stained with Coomassie Blue (BioRad).

DNA isolation, manipulation, and hybridization. Large-scale preparation of plasmid DNA from $C$, piscicola $\mathrm{LV} 17 \mathrm{~A}$ was done by a modification of the Klaenhammer (1984) method. The method was scaled up $10 \times$ using cells from 1 litre of culture grown in APT broth. The resuspended cell solution was carefully adjusted to $\mathrm{pH} 8.0$ for lysozyme treatment, and to $\mathrm{pH} 7.0$ after alkaline lysis. Plasmids were purified by $\mathrm{CsCl}$ density gradient ultracentrifugation (Sambrook et al., 1989). Small- and large-scale plasmid isolation from $E$. coli was done according to Sambrook et al. (1989). Restriction endonucleases and T4 DNA ligase (Boehringer-Mannheim or Bethesda Research Laboratories) were used as recommended by the suppliers. DNA cloning and hybridization were done by methods described by Sambrook et al. (1989). Southern and colony blot hybridizations were done on Hybond $\mathrm{N}$ nylon membranes (Amersham), and DNA probes were labelled with $\left[\gamma^{32} \mathrm{P}\right]$ ATP (Amersham) using T4 polynucleotide kinase (Pharmacia) or with digoxigenin UTP using terminal transferase (Boehringer-Mannheim). Hybridization and washes were done at $30^{\circ} \mathrm{C}$. A degenerate 23-mer oligonucleotide, RWO1 [5'GAXGGXGTXAA(CX)TAXGGXAA(AG)GG3'; X = bromouracil] was used to detect carnobacteriocin $A$ gene(s) in all Southern and colony blot hybridizations. Oligonucleotides prepared as sequencing primers were synthesized on an Applied Biosystems 391 PCR Mate synthesizer.

Molecular cloning of carnobacteriocin A gene(s). Plasmid DNA from $C$. piscicola LV17A was digested with a range of restriction enzymes that have unique restriction sites within the multiple cloning site (MCS) of pUC118. A $2.4 \mathrm{~kb}$ EcoRI fragment that hybridized with the carnobacteriocin probe (RWO1) was cloned into pUC118 and screened by colony blot hybridization for successful clones. Plasmid DNA from $\mathrm{Bac}^{+}$ clones was digested with EcoRI and the $2.4 \mathrm{~kb}$ EcoRI insert was eluted from the gel using a one-step method for isolation of DNA fragments (Heery et al., 1990) and cloned into the MCS of pK194 (Jobling \& Holmes, 1990). Positive pUC118 clones were used to produce single-stranded DNA for sequencing.

Nucleotide sequencing of plasmid DNA. Single- and doublestranded DNA was sequenced by Taq DyeDeoxy Cycle sequencing on an Applied Biosystems 373A sequencer. Singlestranded DNA was sequenced from the pUC118 clone (pRW5.9U) using specific sequence oligonucleotides and the universal primer of pUC118. The complementary strand was sequenced in the double-stranded form using the pK194 clone (pRW4.4K) as the sequencing template. Single-stranded DNA was produced by infecting the $E$. coli clone containing the pUC118 clone with M13K07 helper phage and incubating at $37^{\circ} \mathrm{C}$ with rotary shaking (200 r.p.m.) for $75 \mathrm{~min}$. Kanamycin $(\mathrm{Km})$ was then added to give a final concentration of $75 \mu \mathrm{g} \mathrm{ml} l^{-1}$ and incubation was continued for $18 \mathrm{~h}$. Supernatant containing the progeny phage was harvested by polyethylene glycol precipitation (Applied Biosystems Instruments recommended procedures). Large-scale preparation of single-stranded DNA was done by $50 \times$ scaling up of the same procedure. Opposite orientation nucleotide sequencing of the $2.4 \mathrm{~kb}$ EcoRI fragment was tested on existing positive clones. Opposite orientations were attempted by cutting the clone of $\mathrm{PRW} 5$.9U and religating the pool of fragments.

\section{RESULTS}

\section{Purification and stability of A carnobacteriocins}

Carnobacteria do not grow well below pH 5.0 and do not produce bacteriocin below pH 5.5 (Ahn \& Stiles, 1990a). From the data in Fig. 1 it can be seen that with the $\mathrm{pH}$ held 


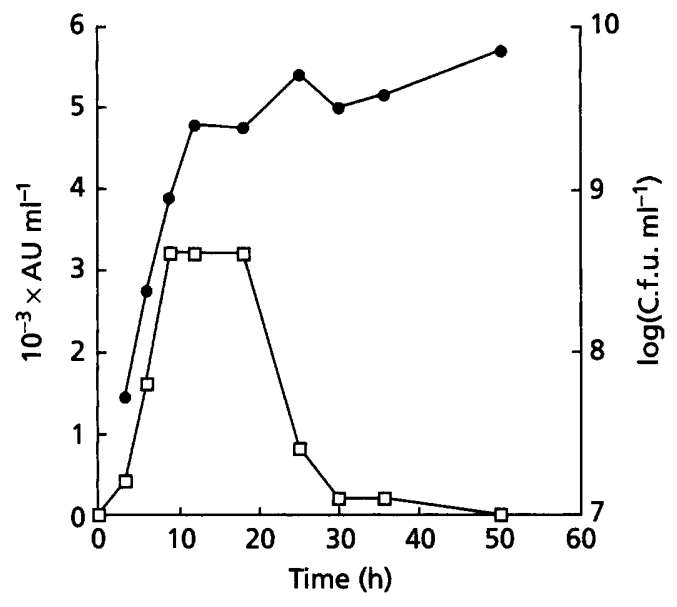

Fig. 1. Bacteriocin production and activity [in arbitrary units (AU)] of carnobacteriocin A produced by $C$. piscicola LV17A with time at constant $\mathrm{pH}$ of 6.0 at $25^{\circ} \mathrm{C} . \square, \mathrm{AU} \mathrm{ml^{-1 }} ; 0, \log$ c.f.u. $\mathrm{ml}^{-1}$.

constant at $6 \cdot 0$ the greatest amount of bacteriocin activity was detected between 9 and $18 \mathrm{~h}$ of incubation at $25^{\circ} \mathrm{C}$. The bacteriocin is unstable and activity decreases rapidly during further incubation. Using the culture supernatant of C. piscicola LV17A grown at $\mathrm{pH} 6.5$ for $18 \mathrm{~h}$ and the purification steps shown in Table 2, a total yield of $4.6 \times 10^{6}$ arbitrary activity units (AU) determined against C. divergens LV13 was obtained. A total of $1.9 \times 10^{6} \mathrm{AU}$ $(41 \%)$ was recovered after purification by reversed-phase HPLC. Following this isolation protocol three extracellular active peptides were observed (Fig. 2) and separated by HPLC. The major product, carnobacteriocin A3, was separated with a yield of about $800 \mu \mathrm{g}$ from 2 litres of culture broth. Carnobacteriocin A2 was obtained with a lower yield of $500 \mu \mathrm{g}$, whereas A1 proved to be a

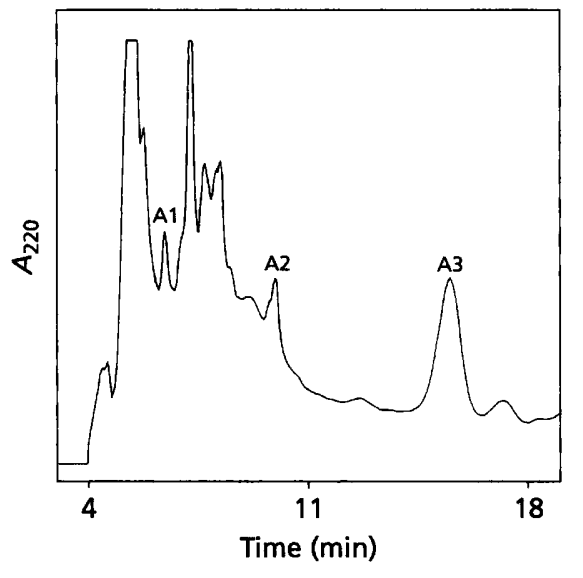

Fig. 2. Elution pattern of carnobacteriocins $A$ on a reversedphase HPLC C-8 column (VYDEC) using $0.1 \%$ TFAMMeCN gradient. Peaks $A 1, A 2$, and $A 3$ represent the active peaks obtained.

mixture of degradation products. Carnobacteriocins A1 and A2 also displayed lower specific activities. Gel electrophoresis indicated molecular masses of approximately $4000 \mathrm{Da}$ (Fig. 3). Although partially purified carnobacteriocins A decomposed rapidly (possibly due to proteolysis), pure lyophilized samples of carnobacteriocins $\mathrm{A} 2$ and $\mathrm{A} 3$ showed no decrease in biological activity and gave clean mass spectra after storage for several months at $4{ }^{\circ} \mathrm{C}$ (Fig. 4). All three bacteriocins were unstable in solution for an extended period of time. During storage at $5{ }^{\circ} \mathrm{C}$ for $14 \mathrm{~d}$ in $0.1 \% \mathrm{TFA}, \mathrm{A} 1$ was completely degraded, A2 was the most stable, with $80 \%$ of its activity remaining, and A3 retained only $10 \%$ of its activity. None of the degradation products isolated by HPLC showed biological activity against $C$. divergens LV13 (data not shown). Data in Table 3 show that

Table 2. Purification of carnobacteriocins A1-A3 produced by C. piscicola LV17A at pH 6.5

\begin{tabular}{|c|c|c|c|c|c|c|c|}
\hline Purification stage & $\begin{array}{l}\text { Volume } \\
\text { (ml) }\end{array}$ & 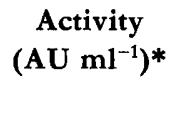 & $\begin{array}{c}\text { Total } \\
\text { activity } \\
\text { (AU) }\end{array}$ & $\begin{array}{c}\text { Amount of } \\
\text { protein } f \\
\left(\mathrm{mg} \mathrm{ml} \mathbf{~}^{-1}\right)\end{array}$ & $\begin{array}{c}\text { Specific } \\
\text { activity } \\
\left(\mathbf{A U ~} \mathbf{m g}^{-1}\right)\end{array}$ & $\begin{array}{c}\text { Activity } \\
\text { recovery } \\
(\%)\end{array}$ & $\begin{array}{c}\text { Purification } \\
\text { (-fold) }\end{array}$ \\
\hline Supernatant & 5800 & $0.8 \times 10^{3}$ & $4.64 \times 10^{6}$ & $3 \cdot 3$ & $2.43 \times 10^{2}$ & 100 & 1 \\
\hline XAD-8 fractions $\ddagger$ & 130 & $3.2 \times 10^{4}$ & $4 \cdot 16 \times 10^{6}$ & $1 \cdot 7$ & $1.94 \times 10^{4}$ & 90 & 80 \\
\hline Sephadex LH-60 fractions $\ddagger$ & 220 & $1 \cdot 28 \times 10^{5}$ & $2 \cdot 88 \times 10^{6}$ & $0 \cdot 17$ & $7 \cdot 9 \times 10^{4}$ & 62 & 325 \\
\hline C-8 column fractions $\ddagger$ & 300 & $0.64 \times 10^{5}$ & $1.92 \times 10^{6}$ & 0.08 & $8.24 \times 10^{4}$ & 41 & 339 \\
\hline \multicolumn{8}{|l|}{ RP-HPLCS } \\
\hline A1 & $0 \cdot 15$ & $0.64 \times 10^{5}$ & $9 \cdot 6 \times 10^{3}$ & $0 \cdot 7$ & $9 \cdot 15 \times 10^{4}$ & & \\
\hline $\mathrm{A} 2$ & 0.92 & $1 \cdot 28 \times 10^{5}$ & $1 \cdot 18 \times 10^{5}$ & $0 \cdot 5$ & $2.56 \times 10^{5}$ & $8 \cdot 6$ & \\
\hline A3 & $0 \cdot 40$ & $6.83 \times 10^{5}$ & $2 \cdot 73 \times 10^{5}$ & $1 \cdot 0$ & $6.83 \times 10^{5}$ & & \\
\hline
\end{tabular}

* AU, activity units determined against Carnobacterium divergens LV13.

† Determined by method of Lowry as modified by Markwell using BSA as a standard (pure sample).

$\ddagger$ Pooled active fractions were concentrated to the given volumes.

$\S$ Active fractions were lyophilized and resuspended in $0.1 \% \mathrm{TFA}$. 


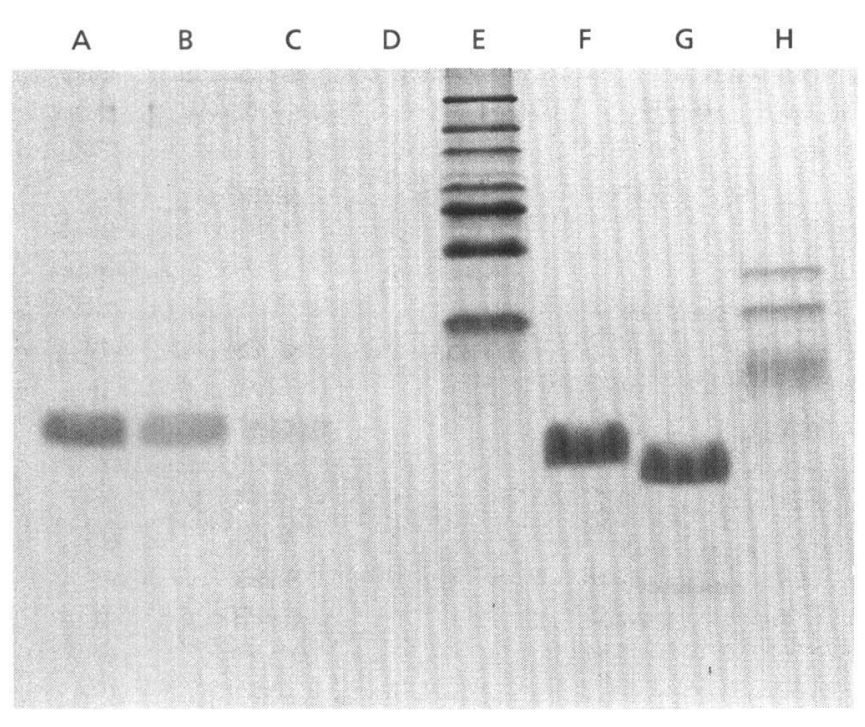

Fig. 3. Polyacrylamide gel $(20 \%)$ electrophoresis of carnobacteriocin A fixed with $5 \%$ formaldehyde and stained with Coomassie blue. Lanes: A, carnobacteriocin A3 $(5 \mu \mathrm{l}) ; \mathrm{B}$, carnobacteriocin A3 $(3 \mu \mathrm{l}) ; C$, carnobacteriocin A3 $(1 \mu \mathrm{l}) ; \mathrm{D}$, blank; $E$, low molecular mass protein standards $-66,45,34 \cdot 7$, 24, 18.4, 14.3 kDa (Sigma); F, nisin; $G$, insulin; $H$, low molecular mass protein standards - 16949, 14404, 8159, 6124 and $2512 \mathrm{Da}$ (Fluka, Biochemika).

carnobacteriocin $\mathrm{A} 1$ is relatively heat stable $\left(100^{\circ} \mathrm{C}\right.$ for $30 \mathrm{~min}$ ) compared with $\mathrm{A} 2$ and $\mathrm{A} 3$. The carnobacteriocins were most stable at $\mathrm{pH} 1.0$ and stability generally decreased with increase in $\mathrm{pH}$. They were stable in the organic solvents tested; in fact enhanced activity was noted in some cases after $24 \mathrm{~h}$ of storage in the solvents. Although the reason for this enhanced activity is uncertain, it may be due to the increase in the population of
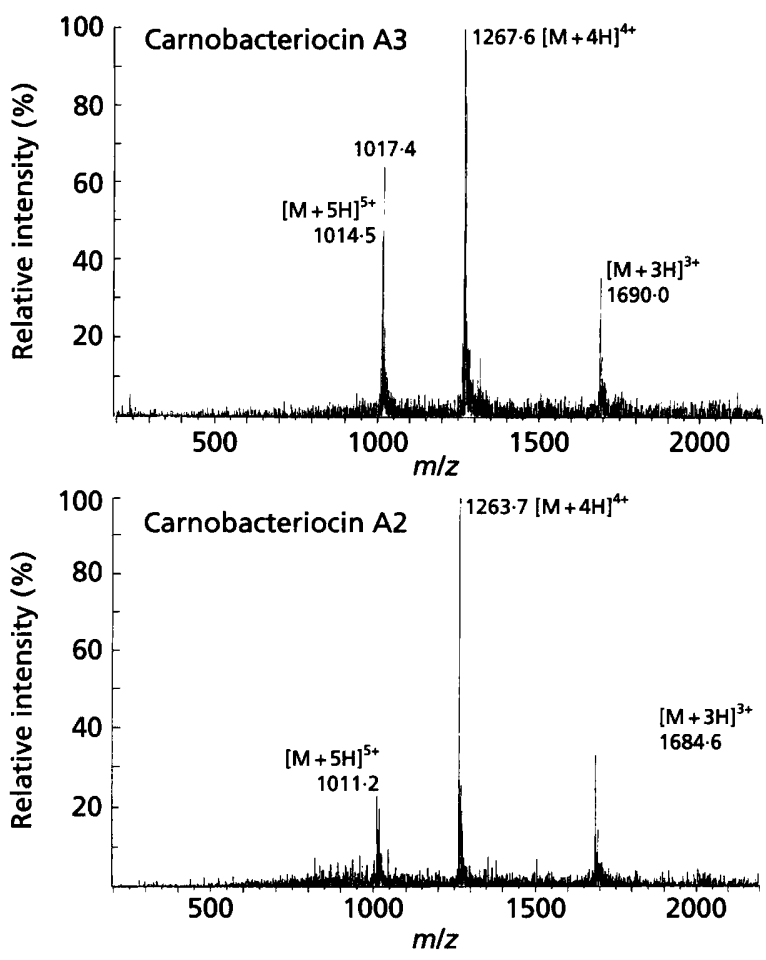

Fig. 4. Electrospray $F A B$ mass spectra (positive ion mode) of carnobacteriocins $\mathrm{A} 2$ and $\mathrm{A} 3$ showing multiply charged molecular ions from which atomic mass was calculated.

an active conformation in the distribution of possible three-dimensional structures caused by the interaction of the lipophilic peptide with organic solvents.

The ratios between the different bacteriocins during growth of the producer strain at $25^{\circ} \mathrm{C}$ at $\mathrm{pH} 6.5$ are

Table 3. Effect of $\mathrm{pH}$, temperature and organic solvents (1:1 mixtures with $0.1 \%$ TFA) on the antimicrobial activity (AU $\mathrm{ml}^{-1}$ ) of the purified carnobacteriocins $\mathrm{A} 1, \mathrm{~A} 2$ and $\mathrm{A} 3$

\begin{tabular}{|c|c|c|c|c|c|c|c|c|c|}
\hline \multirow{3}{*}{$\begin{array}{c}\text { Temp. }{ }^{\circ} \mathrm{C} \ldots \\
\text { Time (h)... }\end{array}$} & \multicolumn{3}{|c|}{ A1 } & \multicolumn{3}{|c|}{ A2 } & \multicolumn{3}{|c|}{ A3 } \\
\hline & \multicolumn{2}{|c|}{25} & \multirow{2}{*}{$\begin{array}{l}100 \\
0.5\end{array}$} & \multicolumn{2}{|c|}{25} & \multirow{2}{*}{$\begin{array}{l}100 \\
0.5\end{array}$} & \multicolumn{2}{|c|}{25} & \multirow{2}{*}{$\begin{array}{l}100 \\
0.5\end{array}$} \\
\hline & 2 & 24 & & 2 & 24 & & 2 & 24 & \\
\hline $0 \cdot 1 \%$ TFA (control) & 1600 & 1600 & 1600 & 200 & 200 & - & 400 & 400 & - \\
\hline $\mathrm{pH} 1$ & 800 & 400 & 400 & 200 & 200 & 200 & 400 & 400 & 0 \\
\hline $\mathrm{pH} 3$ & 800 & 0 & 800 & 200 & 200 & 0 & 400 & 100 & 100 \\
\hline $\mathrm{pH} 5$ & 800 & 100 & 200 & $<100$ & 0 & 0 & 400 & 100 & 0 \\
\hline $\mathrm{pH} 7$ & 200 & $<100$ & 200 & $<100$ & 0 & $<100$ & 200 & 100 & 0 \\
\hline $\mathrm{pH} 9$ & 100 & 0 & 0 & 100 & 100 & 100 & 400 & $<100$ & 0 \\
\hline Ethyl acetate & - & - & - & 200 & 200 & - & 400 & 400 & - \\
\hline Acetonitrile & 1600 & 1600 & - & 200 & 800 & - & 400 & 400 & - \\
\hline Tetrahydrofuran & - & - & - & 200 & 400 & - & 400 & 400 & - \\
\hline Ethanol & 1600 & 1600 & - & 200 & 800 & - & 400 & 1600 & - \\
\hline Methanol & 1600 & 1600 & - & 200 & 400 & - & 400 & 1600 & - \\
\hline Acetone & - & - & - & 200 & 400 & - & 400 & 200 & - \\
\hline
\end{tabular}


Table 4. Ratio of carnobacteriocins produced by $C$. piscicola LV17A during fermentation at $25^{\circ} \mathrm{C}$ in APT broth at $\mathrm{pH} 6.5$

\begin{tabular}{|c|c|c|c|}
\hline \multirow[b]{2}{*}{$\begin{array}{l}\text { HPLC } \\
\text { retention time... } \\
\text { Incubation } \\
\text { time (h) }\end{array}$} & \multicolumn{3}{|c|}{ Activity $\left(\mathrm{AU} \mathrm{m} \mathbf{~}^{-1}\right)$} \\
\hline & $\begin{array}{c}\text { A1 } \\
4 \mathrm{~min}\end{array}$ & $\begin{array}{c}\mathrm{A} 2 \\
19 \mathrm{~min}\end{array}$ & $\begin{array}{c}\mathrm{A3} \\
23 \mathrm{~min}\end{array}$ \\
\hline 9 & 800 & 200 & 200 \\
\hline 18 & 800 & 100 & 100 \\
\hline 26 & 200 & ND & ND \\
\hline 33 & ND & ND & ND \\
\hline
\end{tabular}

ND, Not detected.

shown in Table 4. At the end of the exponential phase of growth the ratios of $A 1: A 2: A 3$ were $4: 1: 1$; this changed to $8: 1: 1$ after another $18 \mathrm{~h}$ of incubation; and after a further $26 \mathrm{~h}$, only A1 could be detected. This is unlike the stability observed with the purified bacteriocins suspended in $0 \cdot 1 \%$ TFA.

\section{Characterization of carnobacteriocins A}

Mass spectral analysis using positive ion fast atom bombardment with an electrospray interface gave multiply charged molecular ions (Fig. 4) which allowed calculation of the average molecular masses as follows: for carnobacteriocin A3, $5050.8 \pm 0.3 \mathrm{Da}$; for A2, $5067.0 \pm 0.3 \mathrm{Da}$; and for the major component of $\mathrm{A} 1$, $4524.7 \pm 0.4 \mathrm{Da}$. Edman degradation of purified samples revealed 16, 20 and 28 amino acids in the $\mathrm{N}$-terminal sequences of samples $\mathrm{A} 1, \mathrm{~A} 2$ and $\mathrm{A} 3$, respectively. The only difference detected between the three compounds was at amino acid residue 16 . After sequencing of 16 to 28
Table 5. Amino acid analysis of carnobacteriocins

\begin{tabular}{|c|c|c|c|c|}
\hline \multirow{2}{*}{$\begin{array}{l}\text { Amino } \\
\text { acid }\end{array}$} & \multicolumn{2}{|c|}{$\mathbf{A} 2$} & \multicolumn{2}{|c|}{ A3 } \\
\hline & pmol & $\begin{array}{l}\text { No. of } \\
\text { residues in } \\
\text { sequence }\end{array}$ & pmol & $\begin{array}{l}\text { No. of } \\
\text { residues in } \\
\text { sequence }\end{array}$ \\
\hline Asn/Asp & 929 & 5 & 3028 & 5 \\
\hline Ala & 1065 & 6 & 3120 & 6 \\
\hline Gly & 2864 & 13 & 19911 & 13 \\
\hline Gln/Glu & 361 & 2 & 1100 & 2 \\
\hline His & 127 & 1 & 377 & 1 \\
\hline Ile & 430 & 2 & 1280 & 2 \\
\hline Leu & 1138 & 6 & 3231 & 6 \\
\hline Lys & 846 & 4 & 2473 & 4 \\
\hline Met & 195 & 1 & 293 & 1 \\
\hline Pro & - & - & 1279 & 2 \\
\hline Ser & 1027 & 6 & 3332 & 6 \\
\hline Thr & 232 & 2 & 734 & 2 \\
\hline Tyr & 238 & 2 & 686 & 2 \\
\hline Val & 424 & 2 & 1314 & 2 \\
\hline
\end{tabular}

amino acids, the accuracy of identification decreased due to background peaks that resulted in a lower confidence level for the identification of the amino acid sequence. The amino acid analyses of the A2 and A 3 bacteriocins are given in Table 5. These amino acid analyses agree with the subsequent results derived from the nucleotide sequence data, except for the failure to detect proline for A2.

\section{Isolation of carnobacteriocin A structural gene}

Plasmid DNA (pCP49 and pCP17) was isolated from $C$. piscicola LV17A and LV17A.17 and digested with restriction enzymes compatible with the multiple cloning site of pUC118 (Fig. 5). A degenerate 23-mer oligo-
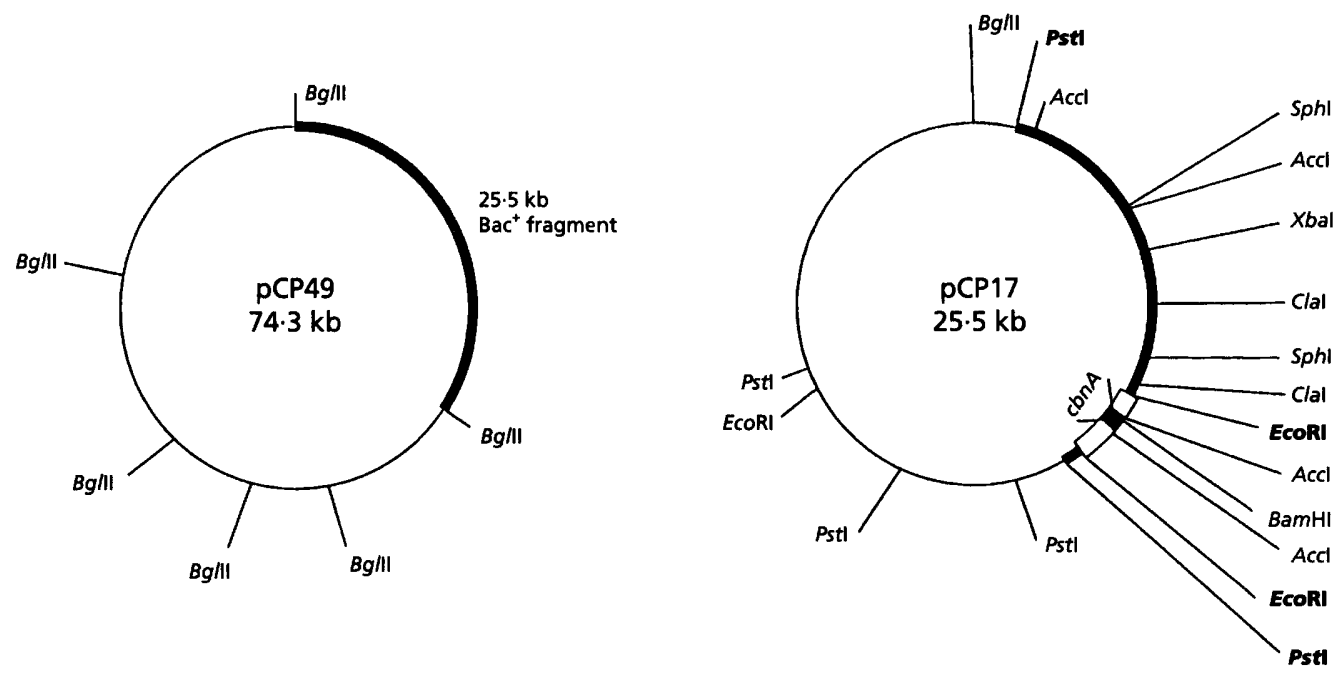

Fig. 5. Restriction maps of pCP49 and pCP17, a religated $25.5 \mathrm{~kb}$ Bg/ll fragment of pCP49 from C. piscicola LV17A. 
Antagonistic peptide carnobacteriocin A

AAAAAAGAAAATTTTTTCTCGATTATTTATTTACTAAATAAATAATgCTATgGTGAGCACATAgCTAAATATgAATATCACTATTACCGA 90

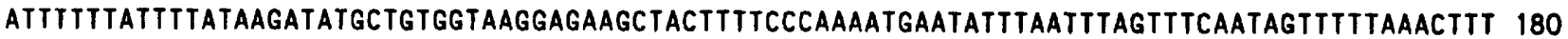

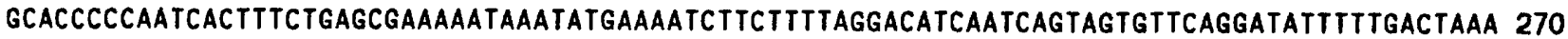

TATCTATTTGgCATGATAGAATGTTCTTGTAACTCAAATAAAATTTAAAgGAgTCTGATTTAGATgAATAATgTAAAAgAgTTAAgTATT 360

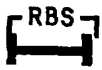

$M \quad N \quad N \quad V \quad K \quad E L S S I$

AAAGAAATGCAACAAGTTACTGGTGGAGACCAAATGTCAGATGGTGTAAATTATGGAAAAGgCTCTAGCTTATCAAAAGgTGGTGCCAAA 450 $\begin{array}{lllllllllllllllllllllllllllllllllll}K & E & M & a & a & V & T & G & G & D & Q & M & S & D & G & V & N & Y & G & K & G & S & S & L & S & K & G & G & A & K\end{array}$

TGTGGTTTAGGGATCGTCGGCGGATTAGCTACTATCCCTTCAGGTCCTTTAGGCTGGTTAGCCGGAGCAGCAGGTGTAATTAATAGCTGT 540 $\begin{array}{lllllllllllllllllllllllllllllll}C & G & L & G & I & V & G & G & L & A & T & I & P & S & G & P & L & G & W & L & A & G & A & A & G & V & I & N & S & C\end{array}$

ATGAAATAAAAAACTCAAATAATTTGAATTTAGACTGTAGACCAAAGAGTTGGATTTAAGTTCCAACTCTTTTTGTCTTTACTATTTAGT 630 M K .

ATtTTTAAAATTAAAAAAAAAGgCCTACTgCCTTTCAATAGTCTCGTAGCTAATTTCTTTGTTTATACTAGTTTAAAAgTGGAACACTTT 720

TTATGGATGTGATGGTTGAAAAGTACACCACTAATAACTCACAATAAGGAGATGAACTTATCTTTTTATTGGAGgAATCAAGAGTGAAAA 810

AATTAATgGaTAAATGTACAATTAAACGTCTAATTGAAAgTGgTCCTTCTCAAAggTCTgTTGCTAAAAAATTAACTATGAATTGCCGCA 900

GAGITGCCCAGATATTGgGTGGAATATCTTCAAGTAAAAGAACCGgTTTCACTTAATCCTTCGgATCCAATAAAAAAGGAACTCATCACG 990

TCTAAACCTACTTATATGAAAACCAATCACAGACCAATAAAGTACACTAAAGAAACGGATAATAGAATTGATGAATTATTAGAATTTGAT 1080

TGTGATAAGgCAAAAAACTGGACGgCATAAACAAAAAACTAATGACAATAAATATTCATGAAATCTTGATTTTCGAAAgTTTTGACATTG 1170

GTGAAAGCACTATTCATTCCTATGTTAgGAAGAAgGTTCAGAAAATAAAAGAAAGCCTTTATCAAgCAAATATATCCTTATTAAAAAAAA 1260

CTGAAAACGTCATCCCTATTGAGATATTTGTCTACAGTCTGAAACTAAAATTAATTTGAGTTTTTTTTTACTTCTTTACATACAACTACT 1350

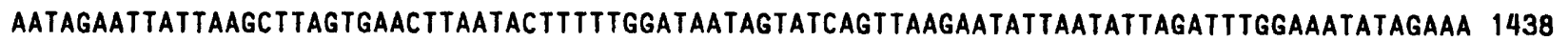

Fig. 6. Single-stranded nucleotide sequence of a $1.4 \mathrm{~kb}$ region within the $2.4 \mathrm{~kb}$ EcoRI fragment of pCP17. The sequence shows one open reading frame commencing at nucleotide residue 334 encoding the structural gene for carnobacteriocin A. The underlined portion represents the 53 amino acid sequence of the mature carnobacteriocin $A$. No other open reading frame was detected. A potential rho-independent termination site is indicated by reversed arrows on the nucleotide sequence between residues 584 and 612. RBS, ribosome binding site.

nucleotide (RWO1) probe was derived from the identical sequence of amino acid residues 5 to 12 of the $\mathrm{N}$-terminus of all three bacteriocins. Hybridization was observed with a $2.4 \mathrm{~kb}$ EcoRI fragment. No other hybridization signal was observed in the remaining EcoRI fragments of pCP49 or when the probe was hybridized with the genomic DNA and pCP40, another native plasmid contained in the wild-type strain of C. piscicola LV17 (Ahn \& Stiles, 1990b). Shotgun cloning of an EcoRI restriction digest of pCP17 into the EcoRI site of pUC118 was performed and colonies were screened using alpha complementation. Colony blots were done to screen the white colonies for the correct insert. The positive clones were digested, Southern transferred and hybridized with the degenerate probe RWO1 to confirm the presence of the carnobacteriocin gene(s).

\section{Nucleotide sequence of the carnobacteriocin A structural gene}

The nucleotide sequence of a $1.4 \mathrm{~kb}$ segment of the $2.4 \mathrm{~kb}$ EcoRI fragment of pCP17 is shown in Fig. 6. Analysis of this sequence revealed the presence of only one open reading frame (ORF) with a probable promoter site. The $\mathrm{N}$-terminal amino acid sequences of carnobacteriocins A2 and A3 matched the sequence derived from nucleotide sequencing. These data indicate that residue 16 in carnobacteriocin A1 is actually serine, as determined by Edman degradation analyses for carnobacteriocins A2 and A3. The first amino acid of the $\mathrm{N}$-terminal sequence matches with the nineteenth amino acid derived from the nucleic acid sequence, so that the prepeptide contains 71 amino acids and is comprised of an N-terminal extension 
consisting of 18 amino acids and the bacteriocin consisting of 53 amino acids. The probable ribosome-binding site (AGGAG) for the carnobacteriocin A $(\operatorname{cbn} A)$ structural gene has the optimal spacing of 9 bases upstream of the initiation codon (coordinate 319). A likely -10 promoter region (TAGAAT) has been identified at position 287 with a TG sequence one nucleotide ahead of the -10 region. Upstream of the -10 region is a potential -35 region located at base pair 262. Downstream of the structural gene there is an 11 base inverted repeat with a 7 base loop that is a potential rho-independent terminator. No significant second ORF was observed in the remaining 800 bases of the $2.4 \mathrm{~kb}$ fragment (see Fig. 6) and a total of 65 stop codons is present across the three possible reading frames. The ends of the $2.4 \mathrm{~kb} E c o \mathrm{RI}$ fragment were identified by the EcoRI sites at each end of the fragment, along with the remainder of the M13/pUC multiple cloning site.

\section{DISCUSSION}

The technique for isolation of leucocin A-UAL 187 reported by Sailer et al. (1993) worked well for the purification of bacteriocins from C. piscicola LV17A. Three peaks (A1, A2 and A3) which had activity against the indicator strain were separated by HPLC. This suggests either that three different bacteriocins are independently produced by de novo protein synthesis, or that subsequent post-translational or chemical modifications of one or more bacteriocins occurs. $\mathrm{N}$-terminal amino acid sequencing of the active substances revealed that at least the first 15 amino acids were identical in each of the three peptides. This result indicates that there is only one parent antibacterial compound (carnobacteriocin A) directly generated from a single structural gene, and that this peptide is subsequently post-translationally transformed to other active derivatives. This was confirmed by experiments with the 23-mer oligonucleotide probe which hybridized with a single restriction fragment. Initial mass spectra for the three compounds isolated by HPLC were ambiguous (not reported) because of relatively rapid decomposition of the samples to complex mixtures. Subsequently, more rigorous HPLC purification gave stable samples that afforded clean fast atom bombardment electrospray mass spectra for compounds $\mathrm{A} 2$ and $\mathrm{A} 3$, and showed that $A 1$ was still an apparently inseparable mixture resulting from degradation at the $\mathrm{C}$-terminal end of the parent bacteriocin. Comparison of the molecular mass of carnobacteriocin A3 (5050.8 $\pm 0 \cdot 3 \mathrm{Da})$ calculated from the mass spectrum to that predicted from the nucleotide sequence $(5052 \cdot 8 \mathrm{Da})$ indicated that this parent bacteriocin contains a disulphide bridge between the two cysteines at positions 22 and 51 but is not otherwise modified. The difference of $+16.2 \mathrm{Da}$ in the molecular mass of $\mathrm{A} 2$ relative to $\mathrm{A} 3$ and the identical results from amino acid sequencing for the first 15 residues of both compounds suggests that carnobacteriocin A2 has the sulphur in methionine 52 oxidized to a sulphoxide. Similar oxidations have been confirmed by detailed structural analyses of carnobacteriocins BM1 and B1 produced by $C$. piscicola LV17B (unpublished data). Thus the actual amino acid sequences of A3 and A2 are identical except for the presence of a methionine sulphoxide at position 52 in A2. Based on the mass spectra for A1, it is assumed that this is a breakdown product of $\mathrm{A} 2$ and $\mathrm{A} 3$.

Activity of carnobacteriocins A was rapidly lost during storage in buffered solutions at $\mathrm{pH}>3$, and the compounds are relatively unstable until completely purified. However, pure samples of A2 and A3 are completely stable for months in lyophilized form. The antimicrobial activity of carnobacteriocins $A$ is relatively stable to organic solvents and heat, especially the breakdown mixture A1. Although a number of low molecular mass, heat-stable, nonlantibiotic, hydrophobic peptide bacteriocins have been purified and characterized from various lactic acid bacteria, carnobacteriocins A3 and A2 have a slightly larger molecular mass and show little amino acid sequence homology with other bacteriocins (Héchard $e t$ al., 1992; Henderson et al., 1992; Holck et al., 1992; Lozano et al., 1992; Marugg et al., 1992; Motlagh et al., 1992; Tichaczek et al., 1992), including carnobacteriocins $\mathrm{BM} 1$ and $\mathrm{B} 2$ produced by the wild-type $C$. piscicola LV17 (unpublished data).

Despite difficulties with stability of purified carnobacteriocin A, as many as 16 to 28 amino acids were determined in the $\mathrm{N}$-terminal sequence for all three compounds. Detection of a single structural gene $c b n A$ on the plasmid pCP49 coding for a serine residue at position 16 of the $\mathrm{N}$-terminal amino acid sequence confirmed that carnobacteriocins A2 and A3 are products of the same gene. The possibility of the structural gene for carnobacteriocin A1 being on the chromosome was excluded by hybridizing the carnobacteriocin probe with the chromosomal DNA. It was concluded that carnobacteriocins A1, $\mathrm{A} 2$ and $\mathrm{A} 3$ have only one structural gene and that initial tentative identification of valine at position 16 of carnobacteriocin A1 resulted from difficulty in interpretation of the Edman degradation data of this apparently inseparable peptide mixture.

Production of more than one bacteriocin by a single organism is not unique. In the case of $C$. piscicola LV17, Ahn \& Stiles (1992) demonstrated that bacteriocin production was mediated by different plasmids. In the case of lactococcins A, B, and M (van Belkum et al., 1991, 1992) all three bacteriocins were shown to be produced by a $60 \mathrm{~kb}$ plasmid in L. lactis subsp. cremoris $9 \mathrm{~B} 4$. Of interest for further study in C. piscicola LV17 is the fact that carnobacteriocins $\mathrm{A}$ and $\mathrm{B}$ are detected early and late in the growth cycle, respectively. It is not clear whether an 'early' bacteriocin, such as carnobacteriocin A or leucocin A-UAL187 (Ahn \& Stiles, 1992; Hastings et al., 1991) is attributable to production of highly active compounds that are detected early in the growth cycle, to differences in copy number of the plasmids promoting higher production, or whether there is genetic control that determines time of production relative to stage of the growth cycle.

Production of lactococcin A by Lactococcus lactis subsp. lactis biovar. diacetylactis WM4 is controlled by a cluster of four genes contained within a $5 \mathrm{~kb}$ fragment of plasmid 
DNA (Stoddard et al., 1992). Upstream of the structural and immunity genes are three ORFs, two of which are implicated in secretion of the bacteriocin through their homology with proteins of signal sequence-independent secretion systems. A similar cluster of four genes from $P$. acidilactici in a $3.5 \mathrm{~kb}$ segment of plasmid DNA was associated with production and secretion of pediocin PA1 in E. coli (Marugg et al., 1992). In this case all genes are located immediately downstream of the structural gene in a relatively compact configuration; however, it was previously shown for this strain of $P$. acidilactici that immunity to its own bacteriocin is chromosomally mediated (Gonzalez \& Kunka, 1987). The structural gene for carnobacteriocin A is located on the $2.4 \mathrm{~kb}$ EcoRI fragment of DNA on which only one ORF was identified, indicating a considerable separation of the structural gene from its immunity and secretion genes. Evidence that the immunity gene is on the same plasmid was obtained by cloning different fragments of DNA downstream of the structural gene of carnobacteriocin A into a plasmidless strain of C. piscicola LV17 (data not shown). Analysis of the genetic control of carnobacteriocin A production is proceeding.

Although carnobacteriocin A differs in molecular size and amino acid composition from other bacteriocins in this group, it is similar to other bacteriocins by having an $\mathrm{N}$ terminal extension that terminates in Gly-Gly residues immediately prior to the cleavage site (Hastings et al., 1991; Holo et al., 1991; Marugg et al., 1992; Muriana \& Klaenhammer, 1991; Stoddard et al., 1992; Van Belkum et al., 1991, 1992). The role of the $\mathrm{N}$-terminal extension in synthesis or secretion of the active bacteriocin has yet to be demonstrated.

In this fragment only one significant ORF was identified and it is the structural gene for carnobacteriocin A. Contained within this region just upstream of the start of the ORF is a probable ribosome-binding site spaced at the optimal number of base pairs upstream of the initiation codon for the carnobacteriocin A structural gene. The -10 promoter region contained a TG sequence upstream. This TG region is conserved in some Gram-positive promoters (Graves \& Rabinowitz, 1986). Earlier work by C. Ahn (unpublished data) indicated that the structural and immunity genes on pCP49 are both on a $5.4 \mathrm{~kb}$ $X b a \mathrm{I}-P_{s t \mathrm{I}}$ fragment. The orientation of the structural gene in the EcoRI fragment indicates that the adjacent EcoRI-XbaI fragment probably contains the immunity gene.

Carnobacteriocin $\mathrm{A}$, as described in this and previous studies (Ahn \& Stiles, 1990a, b, 1992), is an interesting bacteriocin because its early production during the growth of $C$. piscicola LV17 gives the producer organism the potential for an ecological advantage in mixed fermentations. The antibacterial spectrum includes many lactic acid bacteria, and also Enterococcus and Listeria spp. (Ahn \& Stiles, 1990b). Cloning and transformation of the $25.5 \mathrm{~kb} \mathrm{Bg} / \mathrm{II}$ fragment of pCP49 into bacteriocinogenic C. piscicola UAL 26 resulted in the cloned organism acquiring the antibacterial spectrum of both bacteriocins (Ahn \& Stiles, 1992). The ability to produce the cloned bacteriocin in a heterologous $\mathrm{Bac}^{+}$host, with expansion of the activity spectrum of the host strain, encourages the further study of producing 'gene cassettes' of bacteriocins to broaden the antibacterial activity of a producer strain. The immunity and secretion genes have yet to be demonstrated. An understanding of the specific functions of the secretion proteins may allow secretion of several bacteriocins by a single secretion system.

\section{ACKNOWLEDGEMENTS}

This research was funded by a strategic grant from the Natural Sciences and Engineering Research Council of Canada and by a grant from the Alberta Agriculture, Farming for the Future research program.

Dr Robert B. Cody (Jeol USA, Peabody, MA) is gratefully acknowledged for acquisition and expert interpretation of mass spectra. We are grateful for the work done by Gwen Allison, an NSERC summer student, and the technical support and advice given by Alan Hogg, Adam Szpacenko, Ole Sorensen and Lynn Elmes.

\section{REFERENCES}

Ahn, C. \& Stiles, M. E. (1990a). Antibacterial activity of lactic acid bacteria isolated from vacuum-packed meats. J Appl Bacteriol 69, $302-310$

Ahn, C. \& Stiles, M. E. (1990b). Plasmid-associated bacteriocin production by a strain of Carnobacterium piscicola from meat. Appl Environ Microbiol 56, 2503-2510.

Ahn, C. \& Stiles, M. E. (1992). Mobilization and expression of bacteriocin plasmids from Carnobacterium piscicola isolated from meat. J Appl Bacteriol 73, 217-228.

Delves-Broughton, J. (1990). Nisin and its uses as a food preservative. Food Technol 44(11), 100-117.

Graves, M. C. \& Rabinowitz, J. C. (1986). In vivo and in vitro transcription of the Clostridium pasteurianum ferredoxin gene. J Biol Chem 261, 11409-11415.

Gonzalez, C. F. \& Kunka, B. S. (1987). Plasmid-associated bacteriocin production and sucrose fermentation in Pediococcus acidilactici. Appl Environ Microbiol 53, 2534-2538.

Hastings, J. W., Sailer, M., Johnson, K., Roy, K. L., Vederas, J. C. \& Stiles, M. E. (1991). Characterization of leucocin A-UAL 187 and cloning of the bacteriocin gene from Leuconostoc gelidum. J Bacteriol 173, 7491-7500.

Héchard, Y., Dérijard, B., Letellier, F. \& Cenatiempo, Y. (1992). Characterization and purification of mesentericin $Y 105$, an antiListeria bacteriocin from Leuconostoc mesenteroides. J Gen Microbiol 138, 2725-2731.

Henderson, J. T., Chopko, A. L. \& van Wassenaar, P. D. (1992). Purification and primary sequence of pediodin PA-1 produced by Pediococcus acidilactici PAC-1 .0. Arch Biochem Biophys 295, 5-12.

Henkel, T., Sailer, M., Helms, F. L., Stiles, M. E. \& Vederas, J. C. (1992). NMR assignment of leucocin A, a bacteriocin from Leuconostoc gelidum, supported by a stable isotope labeling technique for peptides and proteins. $J$ Am Chem Soc 114, 1898-1900.

Heery, D. M., Gannon, F. \& Powell, R. (1990). A simple method for subcloning DNA fragments from gel slices. Trends Genet 6, 173.

Holck, A., Axelsson, L., Birkeland, S.-E., Aukrust, T. \& Blom, H. (1992). Purification and amino acid sequence of sakacin $A, a$ bacteriocin from Lactobacillus sake Lb706. J Gen Microbiol 138, 2715-2720.

Holo, H., Nilssen, O. \& Nes, I. F. (1991). Lactococcin A, a new 
bacteriocin from Lactococcus lactis ssp. cremoris: isolation and characterization of the protein and its gene. J Bacteriol 173, 3879-3887.

Jobling, M. G. \& Holmes, R. K. (1990). Construction of vectors with the $\mathrm{p} 15$ a replicon, kanamycin resistance, inducible lac $Z \alpha$ and pUC18 or pUC19 multiple cloning sites. Nucleic Acids Res 18, 5315-5316.

Klaenhammer, T. R. (1984). A general method for plasmid isolation in lactobacilli. Curr Microbiol 10, 23-28.

Klaenhammer, T. R. (1988). Bacteriocins of lactic acid bacteria. Biocbimie 70, 337-349.

Laemmli, U. K. (1970). Cleavage of structural proteins during the assembly of the head of bacteriophage T4. Nature 227, 680-685.

Lozano, J. C. N., Meyer, J. N., Sletten, K., Peláz, C. \& Nes, I. F. (1992). Purification and amino acid sequence of a bacteriocin produced by Pediococcus acidilactici. J Gen Microbiol 138, 1985-1990.

Marugg, J. D., Gonzalez, C. F., Kunka, B. S., Ledeboer, A. M., Pucci, M. J., Toonen, M. Y., Walker, S. A., Zoetmulder, L. C. M. \& Vandenbergh, P. A. (1992). Cloning, expression, and nucleotide sequence of genes involved in production of pediocin PA-1, a bacteriocin from Pediococcus acidilactici PAC 1.0. Appl Environ Microbiol 58, 2360-2367.

Motlagh, A. M., Bhunia, A. K., Szostek, F., Hansen, T. R., Johnson, M. C. \& Ray, B. (1992). Nucleotide and amino acid sequence of papgene (pediocin AcH production) in Pediococcus acidilactici $\mathrm{H}$. Lett Appl Microbiol 15, 45-58.

Muriana, P. M. \& Klaenhammer, T. R. (1991). Cloning, phenotypic expression and DNA sequence of the gene for lactacin $F$, an antimicrobial peptide produced by Lactobacillus spp. J Bacteriol 173, 1779-1788.

Sambrook, J., Fritsch, E. F. \& Maniatis, T. (1989). Molecular Cloning.
A Laboratory Manual. Cold Spring Harbor, NY: Cold Spring Harbor Laboratory.

Sailer, M., Helms, G. L., Henkel, T., Niemczura, W. P., Stiles, M. E. \& Vederas, J. C. (1993). ${ }^{15} \mathrm{~N}$ - and ${ }^{13} \mathrm{C}$-labeled media from Anabena sp. for universal isotopic labeling of bacteriocins: NMR resonance assignments of leucocin A from Leuconostoc gelidum and nisin A from Lactococcus lactis. Biocbemistry 32, 310-318.

Shaw, B. G. \& Harding, C. D. (1984). A numerical taxonomic study of lactic acid bacteria from vacuum-packed beef, pork, lamb and bacon. J Appl Bacteriol 56, 25-40.

Stoddard, G. W., Petzel, J. P., van Belkum, M. J., Kok, J. \& McKay, L. L. (1992). Molecular analyses of the lactococcin A gene cluster from Lactococcus lactis subsp. lactis biovar. diacetylactis WM4. Appl Environ Microbiol 58, 1952-1961.

Tichaczek, P. S., Nissen-Meyer, J., Nes, I. F., Vogel, R. F. \& Hammes, W. P. (1992). Characterization of the bacteriocins curvacin A from Lactobacillus curvatus LTH1174 and sakacin P from $L$. sake LTH673. Syst Appl Microbiol 15, 460-468.

Van Belkum, M. J., Hayema, B. J., Jeeninga, R. J., Kok, J. \& Venema, G. (1991). Organization and nucleotide sequences of two lactococcal bacteriocin operons. Appl Environ Microbiol 57, 492-498.

Van Belkum, M. J., Kok, J. \& Venema, G. (1992). Cloning, sequencing, and expression in Escherichia coli of $\operatorname{lcn} B$, a third bacteriocin determinant from the lactococcal bacteriocin plasmid p9B4-6. Appl Environ Microbiol 58, 572-577.

Vieira, J. \& Messing, J. (1987). Production of single-stranded plasmid DNA. Methods Enzymol 153, 3-11.

Received 23 August 1993; revised 8 October 1993; accepted 15 October 1993. 